\title{
Socio-Economic Factors as Determinants of Farm Management Skills Among Broiler Poultry Producers in Botswana
}

\author{
Som P. Baliyan ${ }^{1, ~ *, ~ M i c a h ~ B . ~ M a s u k u ² ~}$ \\ ${ }^{1}$ Department of Agricultural Economics, Education and Extension, Faculty of Agriculture, Botswana University of Agriculture and Natural \\ Resources, Gaborone, Botswana \\ ${ }^{2}$ Department of Agricultural Economics and Management, Faculty of Agriculture, University of Swaziland, Manzini, Swaziland
}

Email address:

spbaliyan@yahoo.com (S. P. Baliyan)

*Corresponding author

\section{To cite this article:}

Som P. Baliyan, Micah B. Masuku. Socio-Economic Factors as Determinants of Farm Management Skills Among Broiler Poultry Producers in Botswana. International Journal of Agricultural Economics. Vol. 2, No. 2, 2017, pp. 27-34. doi: 10.11648/j.ijae.20170202.11

Received: November 18, 2016; Accepted: March 3, 2017; Published: March 18, 2017

\begin{abstract}
When considering the importance of farm management, poor growth and challenges in poultry production, it is important to analyze and understand the current level of the managerial skills and the factors influencing these skills. This descriptive and co-relational study analyzed socio-economic factors influencing farm management skills among broiler poultry producers in Botswana. A valid and reliable questionnaire was used for data collection through a survey of 60 randomly sampled broiler poultry farm operators in Botswana. Data were analyzed through descriptive and inferential statistical tools where by mean, frequency, correlation, t-test and analysis of variance were employed. Findings revealed that socio-economic factors of gender, level of education, experience in poultry farming, farm capacity, number of workers employed, ownership status, training status and financial support status significantly influenced the level of farm management skills. Broiler producers, particularly the female should be trained as the training has significant influence on the level of farm management skills. Financial support should be availed as it attracts producers with higher skill which in turn, increases the efficiency in broilers production. Larger farms should be encouraged enabling the higher productivity of broilers farms.
\end{abstract}

Keywords: Broiler Production, Farm Management, Level of Skills, Management Skills, Poultry Farming

\section{Introduction}

Management plays an important role in organizing and combining the other factors of production for operating an enterprise profitably. Good management is one of the key factors of success in all types of production, including agriculture. To succeed farmers as producers must dedicate much of their time and, pay attention when making management decisions. Also, they should focus on the process of development of management skills (Franks, 2006). Agricultural production has improved, and is being modernized. Therefore, as a higher degree of intensity, specialization and, new technologies are being continuously adopted, production capacities are being expanded, and investments in the production process are being intensified. To understand and cope with these developments and changes in agricultural production, farmers need only to develop but also equip themselves with all the managerial skills (Kay et al., 2008).

Farmers cannot accomplish a goal of successful agricultural enterprise without adequate knowledge of new methods and without having a logical management skill background. As decisions in agriculture can influence changes in the production of agriculture products which in turn affect the productivity in agriculture sector, management skills become vital (Sameti and Naraghi, 2009). Management's role in realizing farm management goals is important (Amini, et al. 2007; AL-Rimawi, et al. 2006; Onuka and Olaiton, 2007). Incorrect decisions are mostly related to the weakness of production factors management and lack of farmer's awareness, information, and technical skills (Yaghobi et al., 2009). Weak management of production factors coupled with economic inefficiency in the 
production enterprises has been identified as major agricultural constraints faced by small scale producers (Allahyari et al., 2011). Therefore, the managers of agriculture production enterprises are considered as the most important agents to control efficiency, productivity and profitability of enterprises.

Poultry production is a very important livestock sector and contributes to fast economic gains (Ezeibe, 2010). Poultry production includes layer and broiler production. Layer chickens are reared for production of eggs while broiler chickens are kept for production of meat. In terms of nutrition, poultry production contributes to national food security. Meat from broiler chickens has become an important dietary component. Poultry meat is a good source of high quality protein as it contains iron, zinc and Bcomplex vitamins except folic acid (Speedy, 2003). The droppings of broilers are a very important source of manure used in crop production (Taha, 2003). Poultry production, because of its fast growth rate, high nutritional status, using limited closed space, lower density and high feed conversion becomes preferred compared to other livestock. It has experienced transformation into a modern and dynamic commercial sector during the last decade. Many countries including Botswana have initiated programmes aimed at improving small-scale poultry as a means of helping provide people socio- economic benefits (Ugwu, 2009). The government of Botswana has supported poultry farming as one of the investment opportunities for its citizens to create employment and alleviate poverty especially among youth through implementation of financial support schemes (Ministry of Agriculture, 2010).

However, poultry farming has not been fully developed and made profitable in developing countries including Botswana because of such reasons as low productivity, weakness in management, inefficiency of enterprises and the practice of traditional production methods (Mirakzadeh, et al., 2010). The challenges in the poultry industry have made one of the most risky enterprises. These challenges include the expansion of the poultry industry, changes in technological development, statutes and regulations, scattered and dispersed industry, low level of skills and knowledge among producers, the dynamic nature of poultry productions, dependence on imported raw materials, high fluctuation of input prices and lack of reliable markets (Aakkula et al., 2002; Sonkkila, 2002; Suutarinen, 2003). The challenges place great demands on the entrepreneurial skills of the poultry producers. To counter challenges and rapid change in the agribusiness sectors including poultry production calls for appropriate development of management skills by farmers for their future viability (Rolls, 2001; AGSP, 2002). The need for farm management skills for producers cannot be understood without analyzing the current level of the managerial skills and socio-economic factors influencing such skills. Therefore, the farmers' skills and knowledge need to be investigated in order to understand the areas farmers need training for maximum production (Laogun 1985).
Considering the importance of farm management skills, poor growth and challenges in poultry production, it is important to analyse and understand the current level of managerial skills of poultry farmers and the factors influencing these skills. Thus, this descriptive and correlational study analysed socio-economic factors and their influence on farm management skills among broiler poultry producers in Botswana. Though it is not possible to change or manipulate the demographics of farmers influence desirable changes in their skills, an environment can be created whereby these demographics can play a role in managerial skills. Therefore, it is important to analyse the influence of socio-economic variables on farm management skills among farmers in order to understand their contribution to possible positive changes in poultry production.

The purpose of this study was to analyze the determinants of farm management skills in broilers poultry producers in Botswana. Three specific objectives that guided the study were:

i. To describe the socio-economic characteristics of broiler poultry producers.

ii. To determine the relationship between the socioeconomic characteristics and level of farm management skills in broiler poultry producers.

iii. To determine the influence of the socio-economic characteristics on the level of farm management skills in broiler poultry producers.

\section{Methodology}

This quantitative study aimed to analyze the determinants of farm management skills among small scale broiler poultry producers in Botswana. The population of the study was the small scale poultry production enterprises (operators) in Botswana. A total of 60 broilers producers were selected through a random sampling technique. Based on the information from literature, a valid and reliable questionnaire was constructed for data collection (Rougoor et al., 1998; Boehlje et al., 2000; Timonen, 2000; Sonkkila, 2002). The questionnaire composed of two sections. The first section had 11 items on personal and social characteristics and economic characteristics of broilers producers. Personal and social characteristics included gender, ownership status, age, decision influencer, and experience in poultry farming. Economic characteristics on the other hand included training status, financial support status, capacity on farm, number of broilers kept and number of workers employed. The second section of the questionnaire was meant to measure the level of farm management skills among broiler producers which contained 63 closed-end items under seven different areas of farm management skills. These were planning skills, accounting and financial management skills, production management skills, product procurement and marketing skills, decision making skills, risk management skills, and specific technical skills.

Data were collected through a survey using a valid and reliable questionnaire. The level of farm management skills 
was measured by a six-point Likert's scale. The respondents were asked to rate item under the farm management skills on the scale $0=$ no skill, $1=$ very low skill, $2=$ low skill, $3=$ moderate skill, $4=$ high skill and, $5=$ very high skill. The validity of the questionnaire was accomplished by a panel of experts in the field of agricultural economics and farm management. The Cronbach's alpha test was conducted to determine the degree of the instrument's reliability. Cronbach's alpha reliability coefficient for farm management skills and was found to be 0.974 . The Cronbach's alpha greater than 0.70 indicated a good reliability instrument (Field, 2005). It was therefore, found suitable for further analysis.

SPSS software ver.23 was used for data analysis where by descriptive and inferential analyses were employed. The socio-economic characteristics of respondents and the levels of farm management skills among the broiler poultry producers were determined through descriptive statistical tools of frequency, percentage, mean and standard deviation. Pearson correlation coefficients were calculated to determine the relationship between the socio-economic characteristics (independent variables) and score of farm management skills (dependent variables). Inferential analyses of the Analysis of variance (ANOVA) and t-test were employed to determine the influence of socio-economic characteristics on the level of farm management skills. The influence of dichotomous nature of socio-economic characteristics (gender, ownership status, rental status, training status and financial support status) was analyzed through-test statistical analysis, whereas One-way analysis of variance was performed to analyse the influence of discrete nature of socio-economic characteristics (age, level of education, decision influencer, experience in poultry farming, number of birds kept, number of workers employed). After performing t-test and analysis of variance test, the scores of farm management skill items were calculated and treated as the dependent variable whereas the socio-economic characteristics of the farmers were considered as independent variables.

\section{Results and Discussion}

\subsection{Socio-Economic Characteristics of Respondents}

Descriptive statistics were employed to analyze the socioeconomic characteristics of respondents in the study. These included gender, ownership status, training status, financial support status, age, capacity on farm, level of education, decision influencer, experience in poultry farming, number of broilers kept and, number of workers employed. The levels, frequency and percentages of socio-economic variables of the respondents are presented in Table 1 . Table 1 indicates that male and female respondents in the study were $53.3 \%$ and $47.7 \%$ respectively. It reflects that there was no gender domination in broiler production as male and female were almost equal in number. More than half of the respondents $(58.3 \%)$ were below 45 years of age, while the remaining $41.7 \%$ respondents were more than 45 years old. It further revealed that the majority of the respondents were within the age range of 16-45 years who were considered to be young agile and active poultry farmers. This implies that youths are mostly engaged in poultry farming in the study area and this confirmed to the findings of Agbamu (1993), who reported, that there was a predominance of medium aged people in the farming population.

Table 1. Socio-economic characteristics of the sampled broiler poultry operators.

\begin{tabular}{|c|c|c|c|}
\hline Variables & Levels of variable & Frequency & Percentage \\
\hline \multirow[t]{2}{*}{ Gender } & Male & 32 & 53.3 \\
\hline & Female & 28 & 47.7 \\
\hline \multirow[t]{5}{*}{ Age } & $16-25$ years & 4 & 6.7 \\
\hline & $26-35$ years & 17 & 28.3 \\
\hline & $36-45$ years & 14 & 23.3 \\
\hline & $46-55$ years & 13 & 21.7 \\
\hline & Over 55 years & 12 & 20.0 \\
\hline \multirow[t]{2}{*}{ Capacity on farm } & Owner & 47 & 78.3 \\
\hline & Manager & 13 & 21.7 \\
\hline \multirow[t]{4}{*}{ Level of education } & Primary education & 5 & 8.3 \\
\hline & $\begin{array}{l}\text { Junior Secondary } \\
\text { education }\end{array}$ & 10 & 16.7 \\
\hline & $\begin{array}{l}\text { Senior Secondary } \\
\text { education }\end{array}$ & 24 & 40.0 \\
\hline & University education & 21 & 35.0 \\
\hline \multirow[t]{6}{*}{$\begin{array}{l}\text { Decision } \\
\text { influencers }\end{array}$} & Parents & 8 & 13.3 \\
\hline & Siblings & 1 & 1.7 \\
\hline & Relatives & 4 & 6.7 \\
\hline & Teachers & 1 & 1.7 \\
\hline & Friends & 2 & 3.3 \\
\hline & Yourself & 44 & 73.3 \\
\hline \multirow[t]{4}{*}{$\begin{array}{l}\text { Experience in } \\
\text { farming }\end{array}$} & Less than 2 years & 22 & 36.7 \\
\hline & 2-4 years & 17 & 28.3 \\
\hline & 4-6 years & 8 & 13.3 \\
\hline & More than 6 years & 13 & 21.7 \\
\hline \multirow[t]{4}{*}{$\begin{array}{l}\text { Number of broilers } \\
\text { kept }\end{array}$} & Less than 5000 & 37 & 61.7 \\
\hline & $5000-10000$ & 11 & 18.3 \\
\hline & $10000-20000$ & 5 & 8.3 \\
\hline & More than 20000 & 7 & 11.7 \\
\hline \multirow[t]{4}{*}{$\begin{array}{l}\text { No of workers on } \\
\text { farm }\end{array}$} & Less than 5 & 37 & 61.7 \\
\hline & $5-10$ & 14 & 23.3 \\
\hline & $10-15$ & 6 & 10 \\
\hline & More than 15 & 3 & 5 \\
\hline \multirow[t]{2}{*}{ Rental status } & Yes & 34 & 56.7 \\
\hline & No & 26 & 43.3 \\
\hline \multirow[t]{2}{*}{ Training status } & Yes & 28 & 46.7 \\
\hline & No & 32 & 53.3 \\
\hline \multirow[t]{2}{*}{ Financial support } & Yes & 13 & 21.7 \\
\hline & No & 47 & 78.3 \\
\hline
\end{tabular}

The results indicated that most of the broilers farmers $(78.3 \%)$ were operated by the owner of the farms, while $27.7 \%$ farms were operated by the employed managers (Table 1). This finding reflected that either the owners were interested in running their farm themselves, or they cannot afford or find suitable managers to operate their farms.

Education level of farmers is often considered effective for decision making and improving the skills. Education helps farmers to respond to challenges, innovation and poultry 
technology, which results in efficiency and high productivity. Therefore, the level of education of farmers was analyzed. The results presented in Table 2 indicate that the highest percentage of respondents $(40 \%)$ possessed senior secondary education followed by university education holders (35\%). Primary level education was obtained by the least respondents $(8.3 \%)$. It indicated that people with low level of education were not attracted by poultry farming in the country. A number of people can influence the decision to start a farm enterprise and it is therefore important to study those people who influence the decision to engage in farming. Most of the respondents (73.3\%) were inspired by themselves followed by their parents (13.3\%). Table 4 shows that $36.7 \%$ of the respondents had maximum of 2 years' experience while $28.3 \%$ of respondents had $2-4$ years of experience in poultry farming. This finding reflected that younger people with less experience were dominating in poultry farming. It also reflected that new generation is more entrepreneurial oriented.

Based on the number of birds kept, the farm size was divided into three categories: small (up to 10000 broilers), medium (10000-20000 broilers) and, large scale farms (more than 20000 birds). The findings revealed that the majority of farms $(80 \%)$ were small. Only $8.3 \%$ respondents were operating medium sized farms, while $11.7 \%$ respondents had large farms. It was therefore, evident that a greater percentage of poultry farmers were small scale farmers. The majority of farmers $(61.7 \%)$ employed less than 5 workers followed by $23.3 \%$ farms which employed 5-10 workers. This finding also supported the fact that the small sized farms were in majority cannot afford to employ a large number of workers. On the other hand, this finding has an implication on farm operation in the sense that the birds kept on small scale farms were up to 10000 birds and it can be difficult to manage such large number of birds effectively with a maximum of ten workers. This scenario may have negative bearing on the productivity of the farms. About fifty seven percent $(56.7 \%)$ of the respondents were renting the farms while $43.7 \%$ were operating their own farms. It suggested that there is still an opportunity to rent a farm if the owners do not operate them and want to rent out their farms. More than half $(53.3 \%)$ of the respondents did not have any training on broiler production. These findings may have implication on the level of farm management skills which obviously has impact on the performance and productivity of the farm. In a way it indicates the need for training in this area of agricultural production in the country. Government has been supporting the agriculture sector as a tool of diversification of the country's economy, but surprisingly, the results indicated that only $21.7 \%$ of the respondents got financial support for broiler production and a majority of farmers $(78.3 \%)$ were running their farms without any financial support. This finding needs to be verified by considering a larger sample. If it is still true then, there is a need to increase financial support to this sub-sector of agriculture.

\subsection{Relationship Between Socio-Economic Factors and the Level of Farm Management Skills}

The Pearson Correlation Coefficients were calculated to determine the relationship between the socio-economic characteristics (independent variables) and farm management skills (dependent variables) among poultry producers. The correlation coefficients are presented in Table 2.

Based on the result in Table 2, it can be concluded that gender $(\mathrm{r}=-.268)$, training status $(\mathrm{r}=-.542)$ and financial support status $(r=-.274)$ have a significant and negative relationship with the level of farm management skills. It indicated that gender, training status and financial support status are negatively correlated with the farm management skills. On the other hand, relationship between farm management skills and capacity on farm $(r=.353)$, the level of education $(\mathrm{r}=.345)$, experience in poultry farming $(\mathrm{r}$ $=.385)$, number of broilers kept $(\mathrm{r}=.516)$, number of workers employed $(\mathrm{r}=.697)$ and ownership status $(\mathrm{r}=.476)$ were significant at $1 \%$ significant level. There is a positive and significant relationship between the graduates' level of education and the level of farm management skills. The results of the study corroborate with Ommani and Chizari (2006), Bashi Ahmad (2005), Khalili (2008), Rafiee Darani and Shahnooshi (2009), Rosta et al., (2008), Ommani (2001) and Hekmat (2011). The finding on ownership status is in line with findings of Sharkey and Davis (2008). A previous study by Kolz et al. (1998) proved that experienced people do have better farm management skill and, therefore, work performance due to their huge amount of knowledge on the tasks needs to be conducted. Age of respondents and decision influencer have negative and insignificant correlation with the level of farm management skills. This finding contradicts the finding of Allahyari et al (2011), Yaghobi et al. (2009), Bashi Ahmad (2005), Laine et al. (2005), Ommani and Nikandish (2010), Yadegari Naeeni (2010) and Hekmat (2011) who reported that there is a positive and significant relationship between the age of graduates and the level of farm management skills. These finding may differ because of differences in societal set up and mind set of the people.

Table 2. Relationship between socio-economic factors and farm management skills of the broiler poultry producers.

\begin{tabular}{llc}
\hline Variables & Correlation Coefficient & Sig \\
\hline Gender & $-.268^{*}$ & .039 \\
Age & -.042 & .750 \\
Capacity on farm & $.353^{* *}$ & .006 \\
Level of education & $.345^{* *}$ & .007 \\
Decision influencer & -.205 & .117 \\
Years in poultry farming & $.385^{* *}$ & .002 \\
Number of broilers kept & $.516^{* *}$ & .000 \\
Number of workers employed & $.697 * *$ & .000 \\
Ownership status & $.476^{* *}$ & .000 \\
Training status & $-.542 * *$ & .000 \\
Financial support status & $-.274 *$ & .034 \\
\hline$* * p \leq 01 * p<.05$ & &
\end{tabular}




\subsection{Influence of Socio-Economic Factors on the Level of Farm Management Skills}

The independent variables were categorical or discreet; hence t-test statistical analysis was employed when the levels of the independent variables were two. One-way analysis of variance was performed when the levels of the independent variable were more than two. Therefore, the results are presented in two sub headings below.

\subsubsection{Influence of Dichotomous Nature of Socio-Economic Factors on Farm Management Skills}

The independent t-test analysis was employed to determine the influence of dichotomous nature of independent variables. The results are presented in Table 3 .

Table 3. Independent t-test of the Influence of Respondents' Socio-economic Factors on Farm Management Skills $(d f=58)$.

\begin{tabular}{lllllll}
\hline Variable & Level & $\mathbf{n}$ & $\overline{\mathbf{x}}$ & SD & t-value & Sig \\
\hline \multirow{2}{*}{ Gender } & Male & 32 & 154.75 & 44.94 & \multirow{2}{*}{$2.11^{*}$} & \multirow{2}{*}{.039} \\
Capacity on & Female & 28 & 129.32 & 48.14 & & \\
farm & Owner & 47 & 136.08 & 45.87 & $-2.87^{* *}$ & .006 \\
& Manager & 13 & 174.69 & 42.07 & & \\
Rental Status & Renting & 34 & 123.15 & 42.21 & $-4.12^{* *}$ & .000 \\
& Not Renting & 26 & 168.69 & 42.65 & & \\
Training Status & Trained & 28 & 170.36 & 44.43 & & \\
& Not Trained & 32 & 118.84 & 36.77 & $4.91^{* *}$ & .000 \\
Financial & Supported & 13 & 167.61 & 50.49 & & \\
Support Status & Not Supported & 47 & 136.04 & 45.23 & $2.17^{*}$ & .034 \\
\hline
\end{tabular}

$* * \mathrm{p} \leq 01 * \mathrm{p}<.05$

Table 3 indicates that gender $(\mathrm{t}=2.11)$, capacity on farm $(\mathrm{t}$ $=-2.87)$, rental status $(\mathrm{t}=-4.12)$, training status $(\mathrm{t}=4.91)$ and financial support status $(\mathrm{t}=2.17)$ showed significant influence on the level of farm management skills. However, the influence of capacity on farm, rental status and training status were significant at $99 \%$ significance level, while the influence of gender and financial support status was significant at $95 \%$. Table 3 indicated that all the dichotomous factors of gender, capacity on farm, rental status, training status and financial support status had significant influence on the level of farm management skills. Given the overall significant influences of gender, capacity on farm, rental status, training status and financial support status, least square significant (LSD) post-hoc analyses were done. Table 3 indicates that the gender of respondents significantly influenced the level of farm management skill. Moreover, male has greater influence $(\overline{\mathbf{x}}=154.75)$ on the farm management skills of farmers as compared to the influence of female farmers $(\overline{\mathbf{x}}=129.32)$. This also indicates that female farmers have low level of farm management skills as compared to male farmers. Therefore, it is suggested that female farmers should be trained in the farm management skills.

Table 3 indicates that the farms operated by managers had higher significant influence on $(\overline{\mathrm{x}}=174.69)$ on the farm management skills as compared to owner operated farms $(\overline{\mathrm{x}}=$ 174.69). It indicated that the owners still lack in management skills, which can be improved through their proper training. Again, if owners are not interested in training themselves, then they are advised to employ a manager to enhance the productivity of the farm. The farmers who have their own farms (not renting) for production, has higher influence $(\overline{\mathrm{x}}=$ 168.69) on the farm management skills as compared to those farmers who are renting farm $(\overline{\mathrm{x}}=123.15)$. This finding suggested that those who have their own farms are more skilled than those who are renting. The farmers who are trained in broiler production have significant higher level influence on farm management skills $(\overline{\mathrm{x}}=170.36)$ than those who are not trained. Therefore, it is suggested that farmers should be trained as this has influence on the level of farm management skills. In the similar way, who have financial support for operating their farms have significant higher influence $(\overline{\mathrm{x}}=167.61)$ towards farm management skills than those who had no financial support in operating their farm $(\overline{\mathrm{x}}$ $=136.04)$. It is, therefore, suggested that the availability of financial support in broiler production can attract operators with higher skill who can then increase the efficient production of broiler meat production.

\subsubsection{Influence of Discrete Nature of Socio-economic Factors on Farm Management Skills}

One way analysis of variance (ANOVA) was employed to investigate the influence of socio-economic factors on the level of farm management skills of broiler producers. The results are presented in Table 4.

Table 4. One-way Analysis of Variance (ANOVA) and Post-Hoc test of the Influence on respondents' Farm Management Skills by discrete nature socioeconomic factors.

\begin{tabular}{|c|c|c|c|c|c|c|}
\hline Variable & $\mathbf{n}$ & $\overline{\mathbf{x}}$ & SD & SE & $\mathbf{F}$ & Sig \\
\hline Age of respondents & & & & & 5.10 & .001 \\
\hline $16-25$ years & 4 & 226.50 & 11.90 & 5.95 & & \\
\hline $26-35$ years & 17 & 121.35 & 34.49 & 8.36 & & \\
\hline $36-45$ years & 14 & 139.07 & 46.15 & 12.33 & & \\
\hline $46-55$ years & 13 & 144.00 & 46.99 & 13.03 & & \\
\hline More than 55 years & 12 & 148.75 & 47.40 & 13.88 & & \\
\hline Educational level & & & & & 2.85 & .045 \\
\hline Junior secondary & 10 & 127.20 & 48.04 & 15.19 & & \\
\hline Senior secondary & 24 & 136.04 & 42.88 & 8.75 & & \\
\hline University & 21 & 164.95 & 51.26 & 11.18 & & \\
\hline Decision influencers & & & & & 3.57 & .007 \\
\hline Parents & 8 & 17.37 & 50.27 & 17.77 & & \\
\hline
\end{tabular}




\begin{tabular}{|c|c|c|c|c|c|c|}
\hline Variable & $\mathbf{n}$ & $\overline{\mathbf{x}}$ & SD & SE & $\mathbf{F}$ & Sig \\
\hline Siblings & 1 & 161.00 & 0.01 & 0.00 & & \\
\hline Relatives & 4 & 93.50 & 28.75 & 14.37 & & \\
\hline Teachers & 1 & 139.86 & 0.01 & 0.00 & & \\
\hline Friends & 2 & 104.50 & 21.92 & 15.50 & & \\
\hline Yourself & 44 & 240.00 & 43.31 & 6.53 & & \\
\hline Experience in farming & & & & & 4.19 & .010 \\
\hline Less than 2 years & 22 & 116.81 & 43.02 & 9.17 & & \\
\hline $2-4$ years & 13 & 150.61 & 47.44 & 13.15 & & \\
\hline 4-6 years & 8 & 160.87 & 40.53 & 14.33 & & \\
\hline More than 6 years & 17 & 163.82 & 45.24 & 10.97 & & \\
\hline No of broilers kept & & & & & 9.18 & .000 \\
\hline Less than 5000 & 37 & 123.24 & 46.01 & 7.56 & & \\
\hline $5000-10000$ & 11 & 148.60 & 34.26 & 10.33 & & \\
\hline $10000-20000$ & 7 & 171.45 & 7.47 & 3.34 & & \\
\hline More than 20000 & 5 & 197.71 & 19.10 & 9.11 & & \\
\hline Number of workers employed & & & & & 19.94 & .000 \\
\hline Less than 5 & 37 & 117.83 & 36.84 & 6.05 & & \\
\hline $5-10$ & 14 & 167.28 & 28.78 & 7.69 & & \\
\hline $10-15$ & 6 & 204.00 & 20.88 & 12.05 & & \\
\hline More than 15 & 3 & 209.83 & 30.60 & 12.49 & & \\
\hline
\end{tabular}

$* * \mathrm{p} \leq 01 * \mathrm{p}<.05$

Table 4 indicates that all the discrete nature variables, namely age of respondents $(\mathrm{F}=5.10, \mathrm{p}=.001)$, education level $(\mathrm{F}=2.85, \mathrm{p}=.045)$, decision influencers $(\mathrm{F}=3.57, \mathrm{p}$ $=.007)$, experience level $(\mathrm{F}=4.19, \mathrm{p}=.010)$, number of broilers kept $(\mathrm{F}=9.18, \mathrm{p}=.000)$ and number of workers employed $(\mathrm{F}=19.94, \mathrm{p}=.000)$ have significant influence on the level of farm management skills among broiler producers.

Given the significant influences of the ages of respondents, education level, decision influencers, experience level, farm size and number of workers employed, least square significant (LSD) post-hoc analyses were done so as to determine the influence at all levels of these factors. Table 4 indicates that the age of respondents significantly influenced the level of farm management skill. Moreover, 16-25 years of age group of farmers has greater influence $(\bar{x}=226.50)$ on the farm management skills followed by that of more than 55 years of age $(\bar{x}=148.32)$. This indicated that younger and older farmers have high level of farm management skills as compared to other age groups. These findings suggested that the younger farmers may have accessed to the education training while the older group may have gained high level of skills through their experience in farming. It is suggested that these groups of farmers can be used to mentor the other group of farmers who have low level of skills in order to enhance farm management skills. Farmers' with university level of education had significantly higher influence $(\overline{\mathrm{x}}=$ 164.95) on the level of farm management levels, followed by secondary level of education $(\overline{\mathrm{x}}=136.04)$ and junior secondary $(\overline{\mathrm{x}}=127.20)$, with the lowest at primary level education $(\bar{x}=114.40)$. It indicated that the higher the farmer's level of education, the higher the influence on the farm management skills. It also reflects that the level of education plays an important role in acquiring the farm management skills. Therefore, farmers' education should be encouraged.

A number of people influence the decision to start broiler production which included parents, siblings, relatives, teachers, friends and the operators themselves. The findings indicated that the operators themselves had the highest significantly influence $(\overline{\mathrm{x}}=240.00)$ on the level of farm management skill, followed by siblings $(\overline{\mathrm{x}}=161.00)$. Parents were the least decision influencers $(\overline{\mathrm{x}}=17.37)$. These findings highlighted the importance of self decision making in an agricultural enterprise. It also reflects that operators are self confident, a good characteristic of a successful entrepreneur. Table 4 also indicates those farmers' with more than 6 years of experience in farming had significantly higher influence $(\overline{\mathrm{x}}=163.82)$ on the level of farm management, followed by 4-6 years of experience $(\bar{x}=160.87)$ and $2-4$ years of experience $(\overline{\mathrm{x}}=150.61)$. The lowest were those who had less than 2 years experience $(\bar{x}=116.81)$. It indicated that the higher the farmer's level of experience, the higher the influence on the farm management skills. It reflects that the farmer's level of experience has an important role in acquiring the farm management skills. However, experience can not be obtained immediately. So, experienced operators can be a good asset to share their experience with the low experienced operators.

Table 4 indicates that farms with more than 20000 birds were found to have significantly more influence $(\bar{x}=197.71)$ followed by farms with $10000-20000$ birds $(\overline{\mathrm{x}}=171.45)$ and farms with $5000-10000$ birds $(\overline{\mathrm{x}}=148.60)$. The farms with a capacity of less than 5000 birds has the least significant influence $(\bar{x}=123.24)$ on the level of farm management skills. It is, therefore, concluded that the higher the farm size, the higher the influence it has on the farm management skills. It can also be suggested that the establishment of larger farms should be encouraged for higher productivity. Farmers with more than 15 workers had significantly higher influence $(\overline{\mathrm{x}}=$ 209.83) on the level of farm management levels, followed by farms with $10-15$ workers $(\overline{\mathrm{x}}=204.00)$ and, 5-10 workers ( $\overline{\mathrm{x}}$ $=167.28)$. The farms with less than 5 workers $(\overline{\mathrm{x}}=117.83)$ showed the lowest significant influence on the farm management skills. It indicated that the higher number of 
workers employed on the farm, the higher the influence on the farm management skills. However, one should be careful of the fact that high number of workers can be uneconomic. Therefore, there is a need to determine the optimal number of workers at different size of farms.

\section{Conclusion and Recommendations}

The study analyzed socio-economic factors as determinants of farm management skills among broiler poultry producers in Botswana. The findings have indicated that most of the broiler farms $(75 \%)$ were operated by the owners of the age between 26 to 55 years of age, out of which $75 \%$ were educated at senior secondary and university level. The majority of operators (73\%) inspired themselves to start broilers production. $58 \%$ of the operators had up to 4 years experience in broiler production. Pearson Correlation coefficients indicated that gender, training status and financial support status has a significant and negative relationship with the level of farm management skills. On the other hand, the level of education, experience in poultry farming, number of broilers kept, number of workers employed and ownership status were highly significant. The ages of respondents and decision influences have negative and insignificant correlation with the level of farm management skills.

The social factors of gender, age, training status, level of education, decision influencer to start poultry farming, and experience in poultry farming had significant influence on the level of farm management skill among the broiler producers. Moreover, male farmers had greater influence on the farm management skills of operators as compared to the influence of female farmers. Therefore, it is suggested that female farmers should be trained to enhance their farm management skills. It was revealed that younger (16-25 years) and old age (more than 55 years) farmers have high level of farm management skills as compared to other (middle) age groups. Therefore, it is suggested that these group of farmers can be exploited as mentor to the other group of farmers (middle age) to enhance farm management skills. The farmers who are trained in broiler production have a significantly higher level influence on farm management skills than those who are not trained. Therefore, it is suggested that farmers should be trained as this has influence on the level of farm management skills. It was also concluded that farmers who are operating their own farms are more skilled than those who are renting.

The economic factors of ownership status, financial support status, number of broilers kept and, number of workers employed significantly influenced the level of farm management skills. It was determined that the farms operated by managers had higher influence on the farm management skills as compared to owner operated farms. It indicated that the owners still lack management skills, which can be improved through their proper training. Those who had financial support operate their farms have significantly higher influence on farm management skills than those who had no financial support. It is, therefore, suggested that the availability of financial support in broiler production can attract operators with higher skill and, this can increase the efficient production of broiler meat production. It was concluded that higher the farm size (number of birds kept), the higher the influence on the farm management skills. It can also be suggested that establishment of larger farms should be encouraged for the higher productivity. It was found that the higher number of workers employed on the farm has higher influence on the farm management skills. However, there is a need to determine the optimal farm size and, number of workers employed at different size categories of broiler farms.

\section{References}

[1] Aakkula, J., Jokinen, P., Lankoski, L., \& Nokkala, M. (2002). Agriculture, the Information Society and Sustainable Development. Agri Food Research Working papers 19. Helsinki Agricultural Research Centre of Finland, Retrieved from http://www.mtt.fi/mtts/pdf/mtts19.pdf.

[2] AGSP, (2002). Farm Management in Extension. Rome: Farm Management and Production Economics Service, FAO. Retrieved from http://www.fao.org/waicent/faoinfo/agricult/ags/AGSP/activiti es.html\#fme/.

[3] Ahmad, B. (2008). Farm management in apricot Trail Promotion in Pakistan. National Agriculture Research, Pakistan Agriculture Research Council, Islamabad.

[4] Allahyari, M. S., Saburi, M. S., \& Keshavarz, F. (2011). Analyzing Farm Management Skills in Poultry Production Enterprises in Iran. Life Science Journal, 8(1), 61-67.

[5] Al-Rimawi, A. S., Karablieh, E. K., Al-Qadi, A. S., \& AlQudah, H. F. (2006). Farmers' Attitudes and Skills of Farm Business Management in Jordan. The Journal of Agricultural Education and Extension, 12(3), 165-177.

[6] Al-Rimawi, A. S., Emad, K. K., \& Abdulfatah, S. A. (2004). An investigation into the perceived farm management and marketing educational needs of farm operators in Jordan. Journal of Agricultural Education, 45(3), 34-43.

[7] Boehlje, M., Dobbins, C., Miller, A. Bechman, J., \& Rausch, A. (2000). Checking Your Farm Business Management Skills. Farm Business Management for the 21st Century. Purdue University, Agricultural Economics. Retrieved from http://www.ces.purdue.edu/extmedia/ID/ID-237, pdf.

[8] Ezeigbe, A. B. C. (2010). Profitable Analysis of Pig Production Under Intensive Management System in Nsukka Local Government Area of Enugu State. International Journal of Economic Development Research and Investment, 1(2), 1654.

[9] Field, A. (2005). Discovering Statistics Using SPSS (2nd ed.). London, UK: Sage Publications.

[10] Franks, J. (2006). The Value of Farm Management Research: A Farm Manager Perspective. Seminar paper on Nordic Association of Agricultural Scientist, Seminar 375, Farm risk management, 14-16 June 2006, Oslo, Norway. 
[11] Hekmat, M. (2011). Analysis of farm management skills of Shushtar Township wheat farmers. MS thesis, Islamic Azad University, Shushtar. Retrieved from http://drommani.com/papers.

[12] Kay, R. D, Edwards, W. M., \& Duffy, P. A. (2008): Farm Management, 6th Edition, McGraw Hill, Higher Education.

[13] Khalili, E. A. (2008). Evaluation of the productivity and sustainability of agriculture water of Shudorvan region of Shushtar city`s wheat farmers. MS thesis, Shushtar: Islamic Azad University, Shushtar.

[14] Laogun (1985). Perception of farmers' training needs: A case study of Soya. Rural Development Project in Oyo State. The Nigerian Journal of Agricultural Extension. 3(1), 12-15.

[15] Lien, G., Flaten, O., Moxnes, J. A., Ebbesvik, M., Koesling, M., \& Steinar, V. P. (2005). Management and Risk Characteristics of Part-Time and Full-Time Farmers in Norway, Review of Agricultural Economics, 28(1), 111-131.

[16] Ministry of Agriculture, (2010). Agricultural Support Schemes Guidelines. Department of Animal Production, Ministry of Agriculture, Government of Botswana, Gaborone, Botswana.

[17] Mirakzadeh, A., Ghyasvand, F., Karami, M., \& Papzan, A. (2010). Analysis of factors affecting performance of industrial poultry production in the Kermanshah Township. Iranian Journal of Research for Development and Agricultural Economics, 40(4), 153-159.

[18] Ommani, A. R. (2001). Determination of the social, economical, and agriculture characteristics of Khuzestan province's wheat farmers regarding the acceptance of low input sustainable agriculture: LISA methods. MS thesis, Tehran: Tarbiyat Modares University.

[19] Ommani, A. R. (2010). Identification of factors affecting the knowledge of agriculture water sustainability among Ahwaz wheat farmers. Journal of Agriculture Promotion and Education, 3(2), 65-77.

[20] Ommani, A. R., \& Chizari, M. (2006). Determination of the social, economical, and agriculture characteristics of Ahwaz, Dezful and Behbahan`s wheat farmers according to the acceptance of low input sustainable agriculture: LISA methods, Journal of Agriculture and Natural Resources Science and Techniques, 10(1).

[21] Ondersteijn, C. J. M., Giesen, G. W. J., \& Huirne, R. B. M. (2003). Identification of Farmer Characteristics and Farm Strategies Explaining Changes in Environmental Management and Environmental and Economic Performance of Dairy Farms. Agricultural Systems, 78, 31-55.

[22] Onuka. A. \& Olaitan, S. O. (2007). Entrepreneurial skills required for Economic Empowerment of youths in Broiler production. Journal of Home Economics Research of Nigeria $3(2), 160-169$.

[23] Rafiee, D. H., \& Shahnooshi, N. (2010). Evaluation of the situation of the farmers of Khorasan Razavi province's cities in facing risky occasions: use of multi-scale planning, Researches of Agriculture Economy, 2(4), 151-164.
[24] Rolls, M. J. (2001). Review of Farm Management in Extension Programs in Central and Eastern European Countries, Working Paper, Food and Agricultural Organization of the United Nations, Rome.

[25] Rosta, K., Farajollah, H. J., Chizari, M., \& Hoseini, M. (2008). Evaluation of promotional mechanisms affecting the risk management of wheat production in Khorasan Razavi province, Journal of Agriculture and Natural Resources Sciences, 15(6), 9-21.

[26] Rougoor, C. W., Trip, G., Huirne, R. B. M. \& Renkema, J. A. (1998). How to Define and Study Farmers' Management Capacity: Theory and Use in Agricultural Economics. Agricultural Economics, 18, 261-272.

[27] Sonkkila, S. (2002). Farmer's Decision-making on Adjustment into the EU. Academic dissertation, publications 34, Helsinki University, Department of Economics and Management. Retrieved from https://oa.doria.fi/bitstream/handle/10024/3328/farmersd.pdf

[28] Speedy, A. W. (2003). Global Production and Consumption of Animal Source Foods. Journal of Nutrition, 133, 4048-4053.

[29] Suutarinen, J. (2003). Occupational Accidents in Finnish Agriculture: Causality and Managerial Aspects for Prevention. Doctoral dissertation, Agriculture food Research Reports 39, Finland, Agricultural Research Centre of Finland. Retrieved from http://www.mtt.fi/met/pdf/met39.pdf.

[30] Taha, F. A. (2003). The poultry sector in middle-income countries and its feed requirements: the case of Egypt. Outlook Report No. WRS03-02. Economic Research Service, USDA. Retrieved from http://www.ers.usda.gov/publications/WRS03/dec03/wrs0302.

[31] Timonen, R. (2000). Entrepreneurship, Management, and Success in Farm Businesses. Academic dissertation, publications 28, Finland, Helsinki University, Department of Economics and Management. Retrieved from http://ethesis.helsinki.fi/julkaisut/maa/talou/vk/timonen/yrittav y.pdf.

[32] Ugwu, D. S. (2009). Baseline Study of Small and Medium Scale Poultry Production in Enugu and Lagos States of Nigeria. World Journal of Agricultural Sciences, 5 (1), 27-33.

[33] Yaaghubi, A., Chizari, M., Pezshkirad, G., \& Foeli, S. (2009). Importance of farm management skills from the viewpoint of Wheat farmers in Tafresh Township. Journal of Agricultural Economics and Development, 17(66), 99-114.

[34] Yaghobi, A., Chizari, M., \& Feali, S. (2009). Agriculture products insurance: appropriate strategies in risk management, Journal of Agriculture Economy and Development, 2(6).

[35] Yadegari, N. M. (2010). Knowledge and skill analysis of Naeen city`s wheat farmers about agriculture water management at drought occasions: crop year of 2008-2009, MS thesis, Shushtar Islamic Azad University. 